\title{
挙児希望患者に対する腹腔鏡下手術の予後に関する検討 Effect of laparoscopic therapy for infertile women
}

\author{
大阪市立総合医療センター 婦人科
}

康 文豪、徳山 治、津田浩史

岡本クリニック

岡本吉夫

\section{【はじめに】}

近年、腹腔鏡周辺機器の進歩や腹腔鏡下手術の 技術向上・工夫により、各種良性婦人科疾患が腹 腔鏡下手術の適応となり施行されている。それに 伴い挙児希望患者に対する腹腔鏡も診断的腹腔鏡 から治療的腹腔鏡へと大きく変化し、不妊原因と なりえるさまざまな疾患に対して腹腔鏡下手術が 施行されている。

今回、当科で行った挙児希望患者に対する腹腔 鏡下手術の予後に関する検討を行い、その有効性 につき検討した。

\section{【対象および方法】}

対象は1994年 3 月から2004年12月までに、画像 診断等で異常を認める器質的疾患例 - 5 年以上の 不妊歴をもつ長期不妊例 - 一定期間の不妊治療歴 をもつ例等の挙児希望患者に対して行なった腹腔 鏡下手術（診断的腹腔鏡は含まない）361例のう ち、生殖補助医療技術（以下ART）の適応とな った52例（両側卵管閉塞などの卵管因子が遺残し た 25 例と運動精子数 $5 \times 10^{6} / \mathrm{ml}$ 未満の男性因子を 有する27例）と術後 6 ケ月以上の追跡ができなか った42例の94例を除く267例を対象に、その後の 妊娠（ART妊娠は含まない）につき後方視的に 検討した。手術方法は、クローズド法（一部オー プン法）アプローチによる気腹法で行い、子宮内 膜症手術 - 卵管癒着剥離術 - 卵管開口術 - 卵巣囊 腫摘出術 - 多囊胞性卵巣焼灼術 - 筋腫核核出術を それぞれの疾患に応じて行い、全例に生理食塩水 による腹腔内洗浄および大量通水を加えた。対象 例（原発性不妊225例、続発性不妊42例）の平均 年齢は31.7 \pm 3.7 歳、平均挙児希望期間は 44 ヶ \pm
22ヶ月であった。なお、統計学処理に $\chi^{2}$ testと Student t-testを使用した。

\section{【結果】}

\section{（1）主術式の内容（図 1）}

対象267例の主術式の内容は、子宮内膜症手術 が159例で、その内訳は病巣蒸散65例、子宮付属 器癒着剥離術30例（卵管瘉着剥離術16例、卵巣癒 着剥離術14例)、チョコレート襄腫に対する処置 が64例（両側性 14例）で体内法39例（両側 8

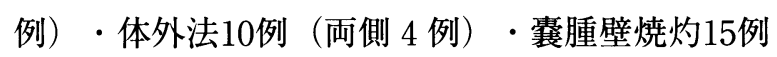
（両側 2 例）であった。子宮内膜症手術以外では 卵管癒着剥離術 28 例（両側13例）、卵管開口術 25 例（両側 23 例 - 片側卵管摘除既往後 2 例)、卵巣 震腫摘出術25例（成熟囊胞奇形腫17例 - 漿液囊胞 腺腫 6 例 - 粘液囊胞腺腫 2 例：両側 3 例：体外法 22例)、多囊胞性卵巣（以下PCO）燒灼術19例、 筋腫核出術 11 例（腹腔鏡補助下 7 例）であった。

\section{図 1 腹腔鏡下手術の主術式の内容}

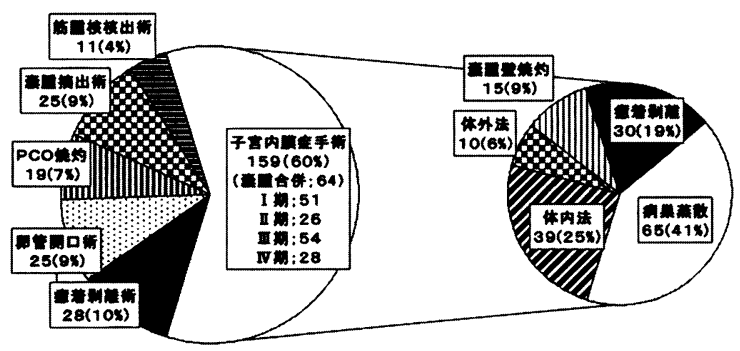

\section{（2）年齢別予後}

36歳以上の例では妊娠率35\%・流産率44\%で、 妊娠例から流産例を除いた妊娠継続率は $19 \%$ と 35 歳以下の $50 \%$ に比べ有意に低かった（図 2 )。そ こで36歳以上の例について検討した場合、36歳・ 37歳の妊娠継続率は35歳以下に比べ低い傾向はあ るものの有意差は認めなかった。しかし、今回の 


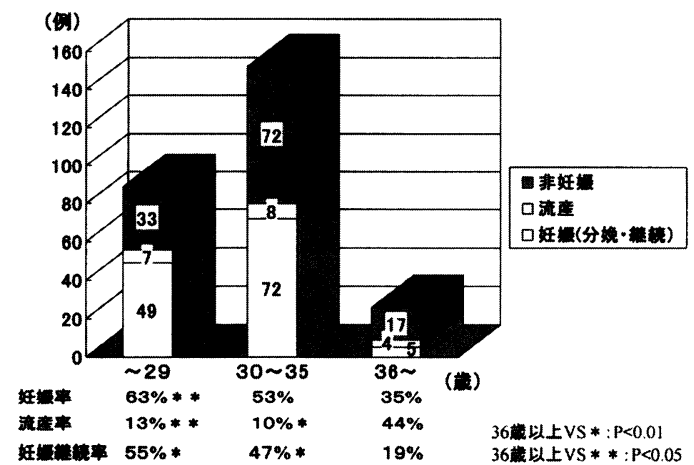

対象の 38 歳以上の 10 例（子宮内膜症 6 例 -子宮筋 腫 4 例）では妊娠例を認めず35歳以下との間に有 意な差（有意差 $1 \%$ 以下）を認めた（図 3 ）。

図 3 36歳以上の症例予後

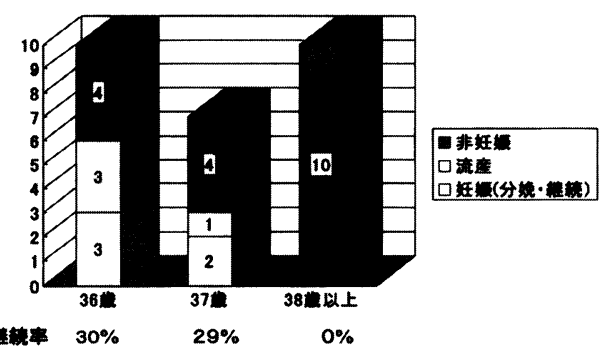

\section{（3）挙児希望期間と予後（図 4）}

挙児希望期間と予後の関係では、挙児希望期間 3 年未満では妊娠率 $60.0 \%$ ・妊娠継続率 $50.9 \%$ で あり 5 年以上の妊娠率 $39.2 \%$ ・妊娠継続率 $31.4 \%$ との間に有意な差を認めた。

\section{図 4 挙児希望期間と予後}

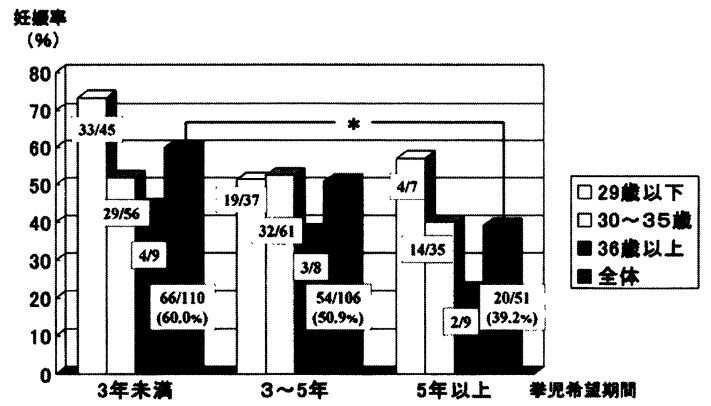

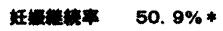

表 1 主術式別予後（子宮内膜症）

\begin{tabular}{|c|c|c|c|c|c|}
\hline 街式 & 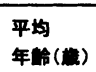 & 例数 & 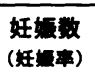 & $\begin{array}{l}\text { 流產数 } \\
\text { (流磨草) }\end{array}$ & 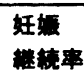 \\
\hline 蒸敞 & $\begin{array}{l}32.4 \\
\pm 3.2\end{array}$ & 65 & $\begin{array}{c}34 \\
(52 \%)\end{array}$ & $\begin{array}{c}3 \\
(9 \%)\end{array}$ & $48 \%$ \\
\hline 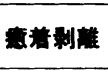 & $\begin{array}{l}32.2 \\
\pm 3.3 \\
\end{array}$ & 30 & $\begin{array}{c}11 \\
(37 \%) \\
\end{array}$ & $\begin{array}{c}1 \\
(9 \%) \\
\end{array}$ & $33 \%$ \\
\hline 体内法 * & $\begin{array}{l}31.3 \\
\pm 3.7\end{array}$ & 39 & $\begin{array}{c}19 \\
(49 \%)\end{array}$ & $\begin{array}{c}4 \\
(21 \%)\end{array}$ & $38 \%$ \\
\hline 体外法* & $\begin{array}{l}29.5 \\
\pm 3.4 \\
\end{array}$ & 10 & $\begin{array}{c}7 \\
(70 \%) \\
\end{array}$ & $\begin{array}{c}1 \\
(14 \%) \\
\end{array}$ & $60 \%$ \\
\hline 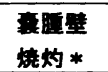 & $\begin{array}{l}34.0 \\
\pm 2.3\end{array}$ & 15 & $\begin{array}{c}8 \\
(53 \%)\end{array}$ & $\begin{array}{c}1 \\
(13 \%)\end{array}$ & $47 \%$ \\
\hline
\end{tabular}

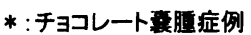

（有意譱なし）

\section{表 2 子宮内膜症期別予後}

\begin{tabular}{|c|c|c|c|c|c|}
\hline & 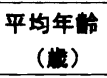 & 例数 & 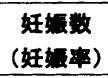 & 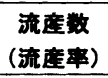 & 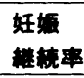 \\
\hline I 期 & $\begin{array}{l}31.9 \\
\pm 3.5\end{array}$ & 51 & $\begin{array}{c}28 \\
(55 \%)\end{array}$ & $\begin{array}{c}3 \\
(11 \%)\end{array}$ & $49 \%$ \\
\hline II期 & $\begin{array}{l}32.3 \\
\pm 2.1 \\
\end{array}$ & 26 & $\begin{array}{c}10 \\
(38 \%)\end{array}$ & 0 & $38 \%$ \\
\hline III期 & $\begin{array}{l}32.1 \\
\pm 3.4\end{array}$ & 54 & $\begin{array}{c}26 \\
(48 \%)\end{array}$ & $\begin{array}{c}7 \\
(27 \%)\end{array}$ & $35 \%$ \\
\hline N期 & $\begin{array}{l}31.2 \\
\pm 4.2\end{array}$ & 28 & $\begin{array}{c}15 \\
(54 \%)\end{array}$ & 0 & $54 \%$ \\
\hline at & $\begin{array}{r}31.9 \\
\pm 3.4 \\
\end{array}$ & 159 & $\begin{array}{c}79 \\
(50 \%)\end{array}$ & $\begin{array}{c}10 \\
(13 \%) \\
\end{array}$ & $43 \%$ \\
\hline
\end{tabular}

（有意美なし）

側・両側で差は認めず、卵管癒着を有する場合の 妊娠継続率 $43 \%$ は卵管瘉着を有しない場合の $44 \%$ と差は認めなかった。また卵管瘉着の重症度につ いての比較において、片側フィルム様で 9 例中妊 娠 2 例、片側強固で12例中妊娠 7 例（流産 1 例）、 両側フィルム様で 6 例中妊娠 4 例、両側強固で 5 例中妊娠 2 例（流産 1 例）、片側がフィルム様・ 片側が強固で 3 例中妊娠 1 例と重症度で差は認め ず、卵管癒着の大きさに関しても、片側 $1 / 3$ 以上 で 10 例中妊娠 7 例、片側 $1 / 3$ 以下で 11 例中妊娠 3 例（流産 1 例）、両側 $1 / 3$ 以上で 4 例中妊娠 2 例、 両側 $1 / 3$ 以下で 6 例中妊娠 5 例 (流産 1 例)、片側 が $1 / 3$ 以上・片側が $1 / 3$ 以下で 4 例中妊娠 1 例と差 は認めず、ASRM分類の卵管瘉着スコア別でも 4 点以下で 21 例中妊娠 9 例（流産 1 例）、 5 点か ら 8 点で 7 例中妊娠 4 例（流産 1 例）、9 点以上 で 7 例中妊娠 4 例と差は認めず、卵管瘉着の程度 での有意な差は認められなかった。次に、病巣蒸 散のみを行った65例について検討したところ、 ASRM分類の腹膜病変スコア 5 点以下で 51 例中 妊娠 28 例（流産 3 例）、 6 点以上では14例中妊娠 6 例と差は認めなかった。また、 6 点では 9 例中 妊娠 5 例に対して7点以上では 5 例中妊娠 1 例と スコアの上昇に伴い妊娠率低下の傾向はあるもの の有意な差は認められなかった。 
(2)非子宮内膜症例

自然妊娠50例（流産 5 例） - 治療妊娠16例（流 産 4 例）で、卵巣囊腫摘出術やPCO焼灼術で高 い妊娠継続率を認めた。筋腫核出術では、他群に 比べ妊娠継続率は低い傾向となったが、平均年齢 が他群より有意に高かった。28例の卵管癒着剥離 術は両側13例中妊娠 7 例（流産 2 例） - 片側15例 中妊娠 8 例 (流産 1 例） と両側・片側で差は認め られなかった。また、一般の不妊治療では妊娠が 期待できない卵管留水腫に対する卵管開口術でも 40\%の妊娠継続率を認めた（表 3 ）。

\section{表 3 主術式別予後}

\begin{tabular}{|c|c|c|c|c|c|}
\hline 衙式 & 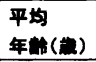 & 城数 & 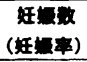 & 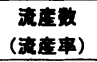 & 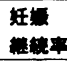 \\
\hline 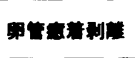 & $\begin{array}{l}30.2 \\
\pm 2.7\end{array}$ & 28 & $\begin{array}{c}15 \\
(54 \%)\end{array}$ & $\begin{array}{c}3 \\
(20 \%)\end{array}$ & $43 \%$ \\
\hline 留管閒口 & $\begin{array}{l}30.5 \\
\pm 3.0\end{array}$ & 25 & $\begin{array}{c}12 \\
(48 \%)\end{array}$ & $\begin{array}{c}2 \\
(17 \%)\end{array}$ & $40 \%$ \\
\hline 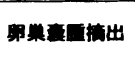 & $\begin{array}{l}30.0 \\
\pm 3.4 *\end{array}$ & 25 & $\begin{array}{c}21 \\
(84 \%)\end{array}$ & 0 & $84 \%$ \\
\hline PCO栳灼 & \begin{tabular}{|l|}
29.9 \\
$\pm 3.5 *$ \\
\end{tabular} & 19 & $\begin{array}{c}15 \\
(79 \%)\end{array}$ & $\begin{array}{c}4 \\
(27 \%) \\
\end{array}$ & $58 \%$ \\
\hline 筋屋核核出 & $\begin{array}{l}35.5 \\
\pm 4.0 \\
\end{array}$ & 11 & $\begin{array}{c}3 \\
(27 \%) \\
\end{array}$ & 0 & $27 \%$ \\
\hline st & $\begin{array}{l}30.7 \\
\pm 3.6\end{array}$ & 108 & $\begin{array}{c}66 \\
(61 \%)\end{array}$ & $\begin{array}{c}9 \\
(14 \%)\end{array}$ & $53 \%$ \\
\hline
\end{tabular}

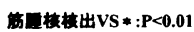

（5）原因不明不妊・長期不妊例の予後

一般不妊検査では器質的異常を認めなかった原 因不明不妊と 5 年以上の不妊歴をもつ長期不妊例 で、診断・治療されたのは子宮内膜症68例、卵管 癒着7例（両側4例）で、子宮内膜症例で妊娠32例 (流産 3 例)、卵管瘉着例で妊娠 2 例認められた。

（6）妊娠例の術後から妊娠成立までの期間（図 5 )

妊娠例145例の術後から妊娠成立までの平均期 間は 10 ケ \pm 9.7 月で、約 $73 \%$ が術後 1 年以内 の妊張成立であった。

図 5 妊娠例の術後から娃娠成立までの期間

(甽)

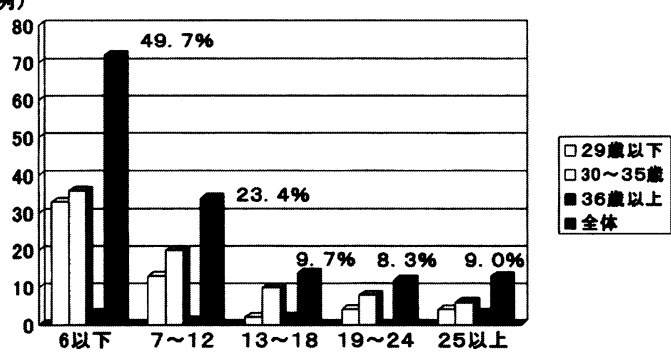

(ヶ月)

（7）妊娠例の術前・術後治療（表 4)

妊娠例145例のうち105例（72\%）が術後自然妊 娠であり、術前の治療までの妊娠成立は 123 例 （85\%）であった。
表 4 妊娠例の術前・術後治療

\begin{tabular}{|c|c|c|c|c|c|c|c|c|c|c|c|c|}
\hline 後 & & 自然 & & & $\mathrm{CC}$ & & & MG & & & 工授 & \\
\hline 前 & \& & 流害 & 18 & 伍) & 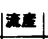 & $\mathbf{s}$ & 纴 & 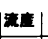 & sh & 姑: & 淁雚 & 3. \\
\hline 自然 & 66 & 5 & 0 & 7 & 2 & 1 & 3 & 0 & 2 & 2 & 0 & 0 \\
\hline $\mathrm{CC}$ & 19 & 4 & 0 & 2 & 0 & 0 & 1 & 1 & 0 & 4 & 1 & 0 \\
\hline hMG & 8 & 3 & 0 & 1 & 0 & 0 & 1 & 0 & 0 & 5 & 1 & 1 \\
\hline 人工授策 & 10 & 1 & 0 & 1 & 0 & 0 & 1 & 0 & 0 & 12 & 1 & 0 \\
\hline 体外受䡛 & 2 & 0 & 0 & 0 & 0 & 0 & 0 & 0 & 0 & 0 & 0 & 0 \\
\hline
\end{tabular}

（8）手術例の経過（図 6)

今回挙児希望患者に対して行った腹腔鏡下手術 361例の経過は、腹腔鏡下手術後の妊娠（ART妊 娠は含まない）は145例で流産は19例であった。 全体の 361 例からみた妊娠率は $39.7 \%$ 、妊娠継続 率は $34.5 \%$ 、全体からART適応例（52例）を除 いた場合の妊娠率は $46.7 \%$ 、妊娠継続率は $40.5 \%$ で、それらょりさらに 6 ヶ月追跡不能例 (42例) を除いた場合、すなわち今回の対象例に対する妊 娠率は $54.3 \%$ 、流産率は $13.2 \%$ で妊娠継続率は $47.2 \%$ あっった。なお、妊娠145例のうち19例に 2 回目の妊娠成立が認められた。

\section{図 6 手術例の経過}

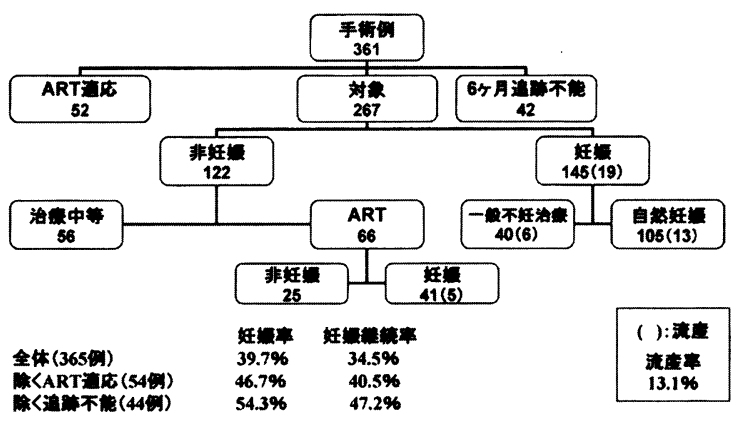

【考察】

不妊症の原因は多種多様で、それに応じて治療 法も様々である。特に、最近のARTの進歩や腹 腔鏡をはじめとした内視鏡下手術の普及により、 不妊治療は飛躍的な進歩とともに選択肢が多様化 している。不妊症患者の治療方法を決定するため には不妊原因を正確に診断することが不可欠であ る。その点で腹腔鏡は原因精査と治療が可能であ り、明らかな器質的疾患を有する例や一般的不妊 検査で何ら異常を認めない例での子宮内膜症や骨 盤内瘉着などの診断・治療にも有用であり、不妊 治療における腹腔鏡は重要な位置を占めると考え られている ${ }^{1.2)}$ 。今回の対象 267 例中 145 例に妊娠 成立が認められたことや、術前には器質的異常を 
認めなかった原因不明不妊や長期不妊で腹腔鏡を 行った75例中 68 例が子宮内膜症、 7 例が卵管癒着 と診断・治療され34例に妊娠成立が認められた事 より腹腔鏡下手術は有用であると考えられた。し かし一般の外来治療で妊娠にいたらない場合にど の段階で腹腔鏡やARTを適応とすべきかが問題 となるが、両方ともに、その後の予後を左右する 因子として年齢が重要な因子として関与する ${ }^{3,4)}$ 。 年齢の上昇とともに妊孕力が低下し、流産率は上 昇することは広く知られており、もともとの不妊 原因とともに加齢による妊孕力の低下という要素 が加わるために治療が困難になっていく。同じ一 般の外来治療を行う場合、腹腔鏡を施行した後の 方が妊娠成立の確率があがると考えられ、適応が あれば早めに腹腔鏡施行が望ましいが、施行にあ たっては患者年齢も考慮する必要がある。今回 38 歳以上の腹腔鏡下手術施行例では妊娠例を認めな かったことと、当科での38歳以上のARTでの患 者当たり妊娠継続率が $30 \%$ あることを考慮する と、38歳以上の例では年齢を考慮した上で早めの ARTの選択など適切な治療法を選択していく必 要があると考える。

不妊原因としての器質的異常に子宮内膜症・卵 管異常・卵巣囊腫・子宮筋腫などがある。なかで も子宮内膜症やクラミジア感染をはじめとした骨 盤内感染の増加に起因する卵管因子の占める割合 は高い。子宮内膜症に伴う妊孕能低下機序は多岐 にわたり、複数因子が同時に関与している場合も あるが、その機序として卵管周囲癒着や卵巣の瘉 着による卵管運動性の障害や卵の捕捉障害、卵巣 チョコレート襄腫による卵胞成育の障害や大きな ものでは卵管と卵巣の位置関係が解剖学的に異常 となり正常な卵管機能を障害する可能性などの機 械的因子や腹水中のプロスタグランジン・各種サ イトカインなどの液性因子の異常やマクロファジ 一などの細胞性因子の異常に伴う腹腔内環境の異 常による受精障害などが考えられており、癒着剥 離や病巣の摘除・焼灼などの手術療法により機械 的因子の解除や腹腔内環境の是正により妊孕性を 向上させる効果が認められ、進行例でも初期病変 例でも子宮内膜症の程度によらず腹腔鏡下手術は 有用であると考えられている ${ }^{5)}$ 。当科における子 宮内膜症患者 159 例の検討でも I - II 期、 III - IV で各々 $45 \% 、 41 \%$ の妊娠継続率が得られた。また、 子宮内膜症例で両側に卵管癒着が認められた場合 著しく妊娠率が低下するとの報告年) もあるが、今 回の我々の検討対象である手術を完遂でき術後直
ちにART対象とならなかった例では、卵管癒着 の有無・片側か両側か・癒着の程度 (重症度 - 大 きさ・癒着スコア)で妊娠率に差は認めなかった。 非子宮内膜症例において、純粋な卵管因子例では ARTか手術療法が選択されるが、より自然に近 い方法で妊娠成功率を向上させる治療法として腹 腔鏡下手術が挙げられ、ARTによらない妊娠も 期待できる。われわれも卵管癒着剥離術 - 卵管開 口術で約 $42 \%$ の妊娠継続率を得ており腹腔鏡下手 術は有用であった。卵管留水腫では、卵管留水腫 内貯留液の子宮腔内への流入によりARTの成績 が悪化するので、卵管切除または開放することに より成功率を上昇させると報告 ${ }^{7,8)}$ されており ART施行前に積極的に腹腔鏡下手術が施行され ている。今回、非内膜症性卵巣囊腫に関して $84 \%$ の高い妊娠継続率を認めたが、当科では $6 \mathrm{~cm}$ 以 上の卵巣囊腫を認める場合、それまでの不妊治療 歴などに関わらず手術を第一選択にしており、今 回の症例の中には手術せずに経過観察や積極的待 機療法を行った場合妊娠成立を認めた症例が含ま れている可能性があり高い効果が認められた事は 否定できないが、卵巣囊腫による患側卵管延長が 囊腫摘出術により改善し、卵管の解剖学的 - 機能 的正常化したことや卵胞成育障害の改善が妊娠機 会増加の一助になったとも考えられる。子宮筋腫 に関しては、直接不妊の原因になるか否かは議論 の多いところであるが、当科では、MRI検查や子 宮卵管造影検査などで子宮内腔異常や卵管延長を 伴うものは手術対象としている。最近では腹腔鏡 （補助）下手術で行われる場合も多くなってきて おり ${ }^{9)}$ 、当科でも適応症例に対しては腹式子宮筋 腫核出術から腹腔鏡（補助）下筋腫核出術へと移 行してきているが、今回の妊張継続率は $27 \%$ と他 の術式に比べ低い傾向があった。その原因として 平均年齢が他群より高かったのが一因とも考えら れた。PCOに関しては、薬剤による排卵誘発無 効例や卵巣過剩刺激症候群既往例に対して手術療 法が行われているが、腹腔鏡下にはPCO焼灼術 が行われており安定した治療効果が報告されてお $\eta^{10,11)}$ 、我々も58\%の妊娠継続率を得た。自然排 卵の回復機序は明らかにはなっていないが、卵巣 焼灼術によりアンドロゲンを含む小囊胞内容液が 卵巣から減少し、FSHが上昇し卵胞発育をさせ る説やインヒビンの減少による説などがあり、卵 巣内の内分泌環境が正常化し、全身の内分泌環境 を改善するものと考えられている。術後の排卵効 果に関しては、卵巣楔上切除での報告 ${ }^{12)}$ では約 
1 年から 2 年とされている。

今回施行した腹腔鏡下手術後のART以外での 妊娠率は $54 \%$ 、流産率は $13 \%$ で妊娠継続率は $47 \%$ であり、妊娠例の $72 \%$ が自然妊娠であった事や ARTと比較すると明らかに単胎妊娠をめざすこ とができ、挙児希望患者に対する腹腔鏡下手術は 有用であると考えられる。しかし、子宮内膜症の 有無、卵管癒着の有無や術式などでその後の予後 に差は認められなかったが、手術施行年齢に関し てはその後の予後に差を認める結果となった事よ り、腹腔鏡下手術は年齢を考慮した上で施行時期 を考えていく必要があると考えられた。また、妊 娠例の $73 \%$ 術後 1 年以内の妊娠成立である事も ふまえると、術後 1 年以上経過した例や 36 歳以上 特に38歳以上の例においてはARTも念頭におき 治療をすすめていく必要があると考えられた。

本論文の要旨は第45回日本産科婦人科内視鏡学会 において発表した。

\section{【文献】}

1) 藤原 浩、小阪謙三、吉岡信也、他：不妊治療に おける腹腔鏡療法の位置づけ、産婦治療、82：1、 2001.

2 ) 大須賀 穣：不妊診療における腹腔鏡の適応と実 際、産婦の世界、53：121、2001.

3 ) 小林善宗、井上正人、鈴木隆弘、他：高年齢不妊 婦人（40才以上）に対する腹腔鏡検査所見の検討、 日産婦内視鏡会誌、10：48、1994.

4 ）間崎和夫、伊藤嘉奈子、渋井幸裕、他：年齢因子 によるARTの成績、日不妊会誌、47：33、2002.

5 ) Marcoux S,Maheax R,Berube S,et al. : Laparoscopic surgery in infertile women with minimal or mild endometriosis. N Engl J Med 337:216,1997.

6 ）大須賀 穣：子宮内膜症合併不妊における腹腔鏡 と予後、エンドメトリオーシス研究会誌、 $22: 33$ 、 2001.

7 ) Strandell A and Lindhard A : Salpingectomy prior to IVF can be recommended to a welldefined subgroup of patients.Hum Reprod 15: 2072,2000 .

8 ）北澤正文、中野貴史、河津 剛、他：卵管留水腫 と体外受精一卵管留水腫摘出の有用性一、受精着 床誌、21：112、2004.

9 ）竹内茂人、菅谷 健、田窪伸一郎、他：不妊症に おける腹腔鏡下子宮筋腫核出術の有用性に関する 比較検討、日産婦内視鏡会誌、19：159、2003.

10）浅田弘法、内田 浩、枝広雅美、他：PCOSに対 する外科手術、産婦の世界、56：555、2004.
11）吉野直樹、有行泰秀、森山政司、他：不妊を合併 する多囊胞性卵单症候群に対する腹腔鏡下多囊胞 性卵巣蒸散術の臨床的検討、日産婦内視鏡会誌、 $20: 222 、 2004$.

12) Lunde O,Djoseland $O$ and Grottum $P$ : Polycystic ovarian syndrome:a follow-up study on fertility and menstrual pattern in 149 patients $15-25$ yeara after ovarian wedge resection. Hum Reprod $16: 1479,2001$. 